\title{
Effect of 1-MCP on Cotton Plants under Abiotic Stress Caused by Ethephon
}

\author{
Yuan Chen ${ }^{*}$, J. T. Cothren', Dehua Chen², Amir M. H. Ibrahim11, Leonardo Lombardini3 \\ ${ }^{1}$ Department of Soil and Crop Sciences, Texas A\&M University, College Station, TX, USA \\ ${ }^{2}$ Jiangsu Provincial Key Laboratory of Crops Genetics and Physiology, Yangzhou University, Yangzhou, China \\ ${ }^{3}$ Department of Horticultural Sciences, Texas A\&M University, College Station, TX, USA \\ Email: ${ }^{*}$ chenyua3@tamu.edu
}

Received 5 July 2014; revised 13 August 2014; accepted 5 September 2014

Copyright (C) 2014 by authors and Scientific Research Publishing Inc.

This work is licensed under the Creative Commons Attribution International License (CC BY).

http://creativecommons.org/licenses/by/4.0/

(c) (i) Open Access

\begin{abstract}
Many environmental stress factors have been identified to increase square and boll abscission and thus result in reduced cotton yield. Under stress conditions, ethylene is elicited. Ethylene peaks before abscission to promote the formation of the abscission layer and plays a major role in early season square and boll abortion in cotton (Gossypium hirsutum L.). In addition, ethylene stimulates the leaf senescence process. Thus, it is desirable to protect plants from ethylene-induced fruit loss and premature leaf senescence under stress conditions. The objective of this study was to evaluate the ability of 1-methylcyclopropene (1-MCP) to protect cotton plants against abiotic stress caused by ethephon (ethylene promoting effect). Field studies using a randomized complete block design with four replications were conducted in 2010 and 2011 at Texas A\&M AgriLIFE Research Farm in Burleson County, TX. Eight treatments that consisted of two 1-MCP rates $(0$ and 10 g a.i. $\left.\mathrm{ha}^{-1}\right)$ in combination with four ethephon rates $\left(0,146,292,438 \mathrm{~mL} \cdot \mathrm{ha}^{-1}\right)$ were imposed at the first flower (FF) stage of the development. 1-MCP increased plant height and number of main stem nodes in both years. In addition, 1-MCP-treated plants exhibited greater membrane integrity and increased photosystem II quantum efficiency and thus delayed senescence in both years. These potentials for yield increase were realized in 2011 with 1-MCP treatment exhibiting a higher lint yield. In 2012, although 1-MCP treatment increased number of open fruit and open fruit weight per plant significantly, no significant lint yield increase was detected.
\end{abstract}

\section{Keywords}

1-MCP, Ethephon, Yield Components, Yield Distribution, Leaf Senescence

\footnotetext{
"Corresponding author.

How to cite this paper: Chen, Y., Cothren, J.T., Chen, D.H., Ibrahim, A.M.H. and Lombardini, L. (2014) Effect of 1-MCP on Cotton Plants under Abiotic Stress Caused by Ethephon. American Journal of Plant Sciences, 5, 3005-3016. 


\section{Introduction}

Ethylene plays a primary role in the abscission of leaves [1]-[3] and fruit [4]. Because boll retention is a major concern for cotton yield improvement, the role of ethylene in cotton fruit shedding has been studied extensively. Ethylene promotes the abscission layer formation in the peduncle in cotton plants, thus leading to fruit abortion [4]. In cotton, research has demonstrated that ethylene production plays a major role in early season square and boll abortion [4]-[7]. Moreover, stress-induced ethylene synthesis can be elicited by temperature that is either high-temperature, freezing, or chilling, water stress including drought and waterlogging, chemicals including herbicides and insects salivary fluids, physical wounding including bruising, cutting and insect biting, and pathogens [8] [9]. Additionally, stresses may further decrease boll retention as confirmed by the fact that ethylene production accelerates induction of fruit shed of cotton plants under drought [2] [5] [10]. Due to the crucial role that ethylene plays in square and boll loss, it is advantageous to protect plants from ethylene-induced fruit loss.

Ethylene is also a mediator in the senescence process in which cells undergo programmed cell death induced by developmental and environmental signals [11]-[13]. When ethylene function was blocked, lower electrolyte leakage, indicating delayed senescence, was detected in flower petals [14]-[16] and leaves [17]. Enhanced chlorophyll degradation associated with ethylene production has been reported in many studies [18]-[21]. Leaf senescence often occurs during the boll filling stage in cotton [22]. At this critical stage, leaf senescence induced by ethylene caused a lower photosynthetic rate and less carbon accumulation and thereby decreased yield. Thus, as mentioned earlier, it is desirable to protect yield by reducing the ethylene effect which can reduce fruit shedding and lead to a delay of senescence.

The plant growth regulator 1-methylcyclopropene (1-MCP), which inhibits ethylene action, has been proven to be a valuable product in industry to improve quality and shelf life of horticultural products [23]. 1-MCP is a gas at room temperature with a formula of $\mathrm{C}_{4} \mathrm{H}_{6}$. 1-MCP occupies the ethylene receptor site and has an affinity 10 times greater for the site than that of ethylene [15] [23]. Thus, 1-MCP may inhibit ethylene action by competing with ethylene for the ethylene receptor to inhibit binding.

Ethephon (2-chloroethylphosphonic acid; Ethrel) is an ethylene-releasing compound that is metabolized to ethylene in plants. Ethephon is a widely used plant growth regulator since the 1960s. This compound is used to facilitate fruit ripening, senescence, abscission, flower induction in pineapple, and to also retard stem growth on cereal crops to reduce lodging. The primary use of this chemical is in cotton harvesting. Ethylene accelerates opening of cotton bolls and improves cotton responses to defoliants; thus ethephon usually makes up a part of defoliation programs [24] [25].

da Costa et al. (2011) [26] tested the effect of ethephon on 1-MCP treated cotton plants. Because we found that 1-MCP works more efficiently in stress conditions (water stress, heat stress, and ageing) (unpublished data), our present study was designed to test effect of 1-MCP under different stress levels applied as different rates of ethephon in the field conditions by assessing leaf senescence traits and yield related data.

\section{Materials and Methods}

The study was conducted at the Texas A\&M AgriLIFE Research Farm in Burleson County on a Westwood silt loam field (fine-silty mixed thermic Fluventic Ustochrept). Cotton cv. FM832LL was seeded on April 10th in 2011 and 2012 at a density of 11 seeds $\mathrm{m}^{-2}$. Each plot had four 1.02 -m-wide rows that were $9.73 \mathrm{~m}$ in length. Furrow irrigation was used when necessary to water plants during the growing season. Fertility, disease prevention, insect and weed control were performed according to the Texas A\&M AgriLIFE Extension Service local recommendations. Harvest aids (1.106 kg a.i. ha ${ }^{-1}$ ethephon plus $0.056 \mathrm{~kg}$ a.i. $\mathrm{ha}^{-1}$ thidiazuron and 0.421 $\mathrm{kg}$ a.i. ha ${ }^{-1}$ tribufos) were applied at approximately $60 \%$ open bolls.

\subsection{Treatment Application and Experimental Design}

Eight treatments were arranged as a randomized complete block design with four replications. They consisted of two rates of 1-MCP ( 0 and $10 \mathrm{~g}$ a.i. $\mathrm{ha}^{-1}$ ) with a $0.0375 \% \mathrm{v} / \mathrm{v}$ surfactant Silwet L77 (Rohm \& Hass, Philadelphia, PA) and four rates of ethephon $\left(0,146,292,438 \mathrm{~mL}^{-h^{-1}}\right.$ ) (PREP, Bayer Crop Science). At first flower stage of development, 1-MCP was applied according to specified treatments in July $7^{\text {th }} 2011$ and June $25^{\text {th }}$ 2012. Ethephon was applied as a source of stress after 24 hrs. Foliar spray was applied according to treatments with 103 $\mathrm{L} \cdot \mathrm{ha}^{-1}$ water and a compressed air sprayer using $8002 \mathrm{XR}$ nozzles. 


\subsection{Data Collection}

At 1, 3, and 5 days after ethephon application, electrolyte leakage and chlorophyll fluorescence measurements were taken at 11 a.m. Membrane leakage was measured to show the level of plasma membrane integrity using the method of Djanaguiraman et al. [27] with some modification. Five 1-cm-diameter leaf discs from the fifth fully extended uppermost leaf were sampled and incubated in $10-\mathrm{mL}$ of double distilled water $\left(\mathrm{ddH}_{2} \mathrm{O}\right)$ in glass tubes at room temperature. After $48 \mathrm{~h}$ of incubation, initial electrical conductivity (IEC) was taken using a calibrated conductivity meter (Oaklon CON11, EUTECH instrument, IL). Leaf discs were then autoclaved at $120^{\circ} \mathrm{C}$ for $15 \mathrm{~min}$. After the solution cooled to room temperature final electrical conductivity (FEC) was measured, and the membrane damage was calculated from the equation: Membrane damage $=($ IEC/FEC $) * 100$.

Chlorophyll fluorescence was obtained in light adapted leaves at the fourth position from the uppermost fullyexpanded leaves with a fluorometer (PAM-2100, Walz, Germany). The value of Yield ( $\left.\Phi_{\mathrm{PSII}}\right)$, used to reflect photosystem II effective quantum efficiency, was the ratio of number of photons absorbed to number of photons emitted by fluorescence. Stressed plants usually exhibit lower $\Phi_{\mathrm{PSII}}$ values because the number of photons absorbed tends to be lower under stressed conditions.

Immediately before machine harvest, 5 randomly chosen plants from the two center rows per designated plot were sampled to conduct box-mapping according to da Costa et al. [26]. Box mapping was used to determine number of vegetative, reproductive, and main-stem nodes, boll weight, plant height, and boll number by individual position and node to determine yield distribution within the canopy. Internode length was measured as the fraction of plant height to main-stem node number. Two weeks after harvest aid application, the two center rows were harvested with a two-row spindle picker.

\subsection{Data Analysis}

Data were subjected to analysis of variance using ANOVA of SAS 9.3 (SAS Institute, NC). Multiple mean comparisons were made using the LSD test at $\mathrm{P} \leq 0.05$.

\section{Results}

\subsection{Lint Yield}

Treatment effect on lint yield was variable for the two years; there were also significant treatment and year interactions. Thus, data was analyzed by each year. Orthogonal contrast in 2011 showed a significant 1-MCP effect, with 1-MCP-treated plants exhibiting a higher lint yield than untreated plants (Table 1). It was noted that the yield enhancement effect of 1-MCP was more evident under ethephon stress rather than when ethephon was absent. In 2011, 1-MCP plus ethephon treatments increased lint yield by $11 \%, 15 \%, 18 \%$, and $12 \%$ at ethephon rates of $0,146,292$, and $438 \mathrm{~mL} \cdot \mathrm{ha}^{-1}$, respectively, compared to their corresponding ethephon treatment alone. The greatest contribution to this increase of yields was from 1-MCP treatment under the ethephon rate of 292 $\mathrm{mL} \cdot \mathrm{ha}^{-1}$. 1-MCP plus $292 \mathrm{~mL} \cdot \mathrm{ha}^{-1}$ ethephon treatment increased lint yield by $18 \%$ compared to $292 \mathrm{~mL} \cdot \mathrm{ha}^{-1}$ ethephon treatment alone. In contrast, the smallest contribution to the increase of yields was from 1-MCP treatment in absence of ethephon. 1-MCP effect was compromised in absence of ethephon (Figure 1(a)). A similar result was observed in the year 2012 with 1-MCP treatment exhibiting no effect on lint yield in absence of ethephon treatment. However, no 1-MCP effect in 2012 was detected by orthogonal contrast as in the year 2011 (Table 1). This observation was caused by the variant effect of 1-MCP under different ethephon rates in 2012. 1-MCP exhibited a positive effect on yield under $438 \mathrm{~mL} \cdot \mathrm{ha}^{-1}$ ethephon. $438 \mathrm{~mL} \cdot \mathrm{ha}^{-1}$ ethephon plus 1-MCP treatment increased lint yield significantly compared to the $438 \mathrm{~mL} \cdot \mathrm{ha}^{-1}$ ethephon treatment alone. In contrast, 1-MCP exhibited a negative effect on yield under $292 \mathrm{~mL} \cdot \mathrm{ha}^{-1}$ ethephon with the $292 \mathrm{~mL} \cdot \mathrm{ha}^{-1}$ ethephon plus 1-MCP treatment decreasing lint yield significantly in contrast to the $292 \mathrm{~mL} \cdot \mathrm{ha}^{-1}$ ethephon treatment alone (Figure 1(b)). However, the effect of 1-MCP under $292 \mathrm{~mL} \cdot \mathrm{ha}^{-1}$ ethephon contributed most to the overall lint increase caused by 1-MCP in 2011 (Figure 1(a)), this unexpected 1-MCP effect at the $292 \mathrm{~mL} \cdot \mathrm{ha}^{-1}$ of ethephon in 2012 disagrees with the 2011 results. There was not clear explanation for this result based on the collected data. The ethephon effect on lint yield was evident in 2012. Orthogonal contrast indicated that ethephon treatment decreased lint yield compared to all other treatments that did not receive ethephon application in 2012 (Table 1). Additionally, $438 \mathrm{~mL} \cdot \mathrm{ha}^{-1}$ ethephon treatment had a lower lint yield compared to the untreated control in 2012 (Figure 1(b)). 
Table 1. The effect of 1-MCP and ethephon on cotton lint yield, open fruit weight per plant, open fruit weight per boll, open fruit number per plant in 2011 and 2012. Same letters within each column represent non-significant differences $(P=0.05)$.

\begin{tabular}{|c|c|c|c|c|c|c|c|c|c|c|}
\hline \multirow{3}{*}{ Treatment } & \multirow{2}{*}{ 1-MCP } & \multirow{2}{*}{ Ethephon } & \multicolumn{2}{|c|}{ Lint yield } & \multicolumn{2}{|c|}{ Open fruit weight } & \multicolumn{2}{|c|}{ Open fruit number } & \multicolumn{2}{|c|}{ Open fruit weight } \\
\hline & & & 2011 & 2012 & 2011 & 2012 & 2011 & 2012 & 2011 & 2012 \\
\hline & g a.i. ha ${ }^{-1}$ & $\mathrm{~mL} \cdot \mathrm{ha}^{-1}$ & \multicolumn{2}{|c|}{$\mathrm{kg} \cdot \mathrm{ha}^{-1}$} & \multicolumn{2}{|c|}{$\mathrm{kg} \cdot$ plant $^{-1}$} & \multicolumn{2}{|c|}{ no. plant ${ }^{-1}$} & \multicolumn{2}{|c|}{$\mathrm{kg} \cdot \mathrm{boll}^{-1}$} \\
\hline 1 & 0 & 0 & 1115abc & $1545 a$ & 70.49ab & 69.33ab & $15.60 \mathrm{a}$ & 13.07ab & $4.48 \mathrm{a}$ & $5.29 \mathrm{a}$ \\
\hline 2 & 0 & 146 & 1109abc & 1429abc & 63.31ab & 53.76bc & $13.47 \mathrm{a}$ & $10.67 \mathrm{ab}$ & 4.71a & $5.04 \mathrm{a}$ \\
\hline 3 & 0 & 292 & $1004 b c$ & 1505ab & 63.52ab & 57.13abc & $13.67 \mathrm{a}$ & 11.27ab & $4.62 \mathrm{a}$ & $5.07 \mathrm{a}$ \\
\hline 4 & 0 & 438 & $895 c$ & $1345 b c$ & $53.07 \mathrm{~b}$ & $49.99 \mathrm{c}$ & $11.73 a$ & $9.87 b$ & $4.51 \mathrm{a}$ & $5.07 \mathrm{a}$ \\
\hline 5 & 10 & 0 & 1238ab & $1575 a$ & 71.79ab & $65.27 \mathrm{abc}$ & $15.47 \mathrm{a}$ & 12.53ab & $4.70 \mathrm{a}$ & $5.20 \mathrm{a}$ \\
\hline 6 & 10 & 146 & $1278 a$ & 1425abc & 82.83a & 72.90a & $16.67 \mathrm{a}$ & 13.80a & $4.96 a$ & $5.30 \mathrm{a}$ \\
\hline 7 & 10 & 292 & 1186ab & $1306 \mathrm{c}$ & 75.08ab & 56.11abc & $16.87 \mathrm{a}$ & 11.13ab & $4.41 \mathrm{a}$ & $5.04 \mathrm{a}$ \\
\hline \multirow[t]{2}{*}{8} & 10 & 438 & $1005 \mathrm{bc}$ & $1560 a$ & 61.02ab & $73.10 \mathrm{a}$ & $13.13 a$ & 13.60a & 4.88a & $5.42 \mathrm{a}$ \\
\hline & \multicolumn{2}{|c|}{$\operatorname{LSD}(0.05)$} & 252 & 180 & 28.40 & 17.87 & 5.60 & 3.41 & 0.55 & 0.64 \\
\hline \multicolumn{11}{|c|}{ Orthogonal contrast } \\
\hline \multicolumn{3}{|c|}{ Ethephon vs. ethephon + 1-MCP } & * & NS & NS & * & NS & * & NS & NS \\
\hline \multicolumn{3}{|c|}{ 1-MCP vs. 1-MCP absent } & $*$ & NS & NS & $*$ & NS & NS & NS & NS \\
\hline \multicolumn{3}{|c|}{ Control vs. ethephon } & NS & NS & NS & $*$ & NS & NS & NS & NS \\
\hline \multicolumn{3}{|c|}{ 1-MCP vs. 1-MCP + ethphon } & NS & NS & NS & NS & NS & NS & NS & NS \\
\hline \multicolumn{3}{|c|}{ Ethephon vs. ethephon absent } & NS & $*$ & NS & NS & NS & NS & NS & NS \\
\hline
\end{tabular}

*Significantly different at $\mathrm{P}=0.05$.

The overall 1-MCP effect was noted in 2011 according to orthogonal contrast, but no significant effect was observed under each individual ethephon rate. This observation was likely due to the high variance of the lint yield data: the coefficient of variation (CV\%) for 2011 lint yield data was 13.7\% whereas the CV\% for that of 2012 was 8.4\%. Also in 2011 one outlier was removed which dropped the CV\% from 15.9\% to 13.7\%. This high CV\% observed in 2011 was likely associated with the drought and heat stress conditions of that year (Figure 2).

\subsection{Yield Components}

Analysis of yield components showed that the number of open fruits than weight per boll contributed more to the difference of open fruit weight per plant caused by 1-MCP treatment (Table 1). In the year 2012, there was a significant 1-MCP effect on the number of open fruit. 1-MCP pretreatment increased number of open bolls under stress imposed by ethephon application according to the orthogonal contrast. This beneficial effect of 1-MCP on boll number, together with the numerical increase of weight per boll, contributed to higher boll weight per plant in 2012. However, the beneficial effect of 1-MCP on yield components in 2012 did not result in higher yield. This result was due to the unexpected 1-MCP effect on yield under $292 \mathrm{~mL} \cdot \mathrm{ha}^{-1}$ ethephon. In 2012, 1-MCP exhibited a negative effect on yield under $292 \mathrm{~mL} \cdot \mathrm{ha}^{-1}$ ethephon with the $292 \mathrm{~mL} \cdot \mathrm{ha}^{-1}$ ethephon plus 1-MCP treatment decreasing lint yield significantly in contrast to the $292 \mathrm{~mL} \cdot \mathrm{ha}^{-1}$ ethephon treatment alone. Thus, this negative effect of 1-MCP effect under $292 \mathrm{~mL} \cdot \mathrm{ha}^{-1}$ ethephon offset its positive effect on cotton yield under other ethephon rate. In addition, the orthogonal contrast also indicated a lower boll weight per plant for treatments receiving ethephon compared to the untreated ones in 2012 (Table 1). Previous reports also have shown that high rates of ethephon caused small bolls [28]. This result is consistent with the lint yield data which also exhibited a significant ethephon effect in 2012. In the year 2011, neither 1-MCP nor ethephon showed a significant effect on yield components. Although open fruit weight per plant in 1-MCP treated plants was numerically greater than corresponding untreated plants under all different ethephon rates, no significant difference was detected due to a comparatively large variance in sample data (Table 1). 


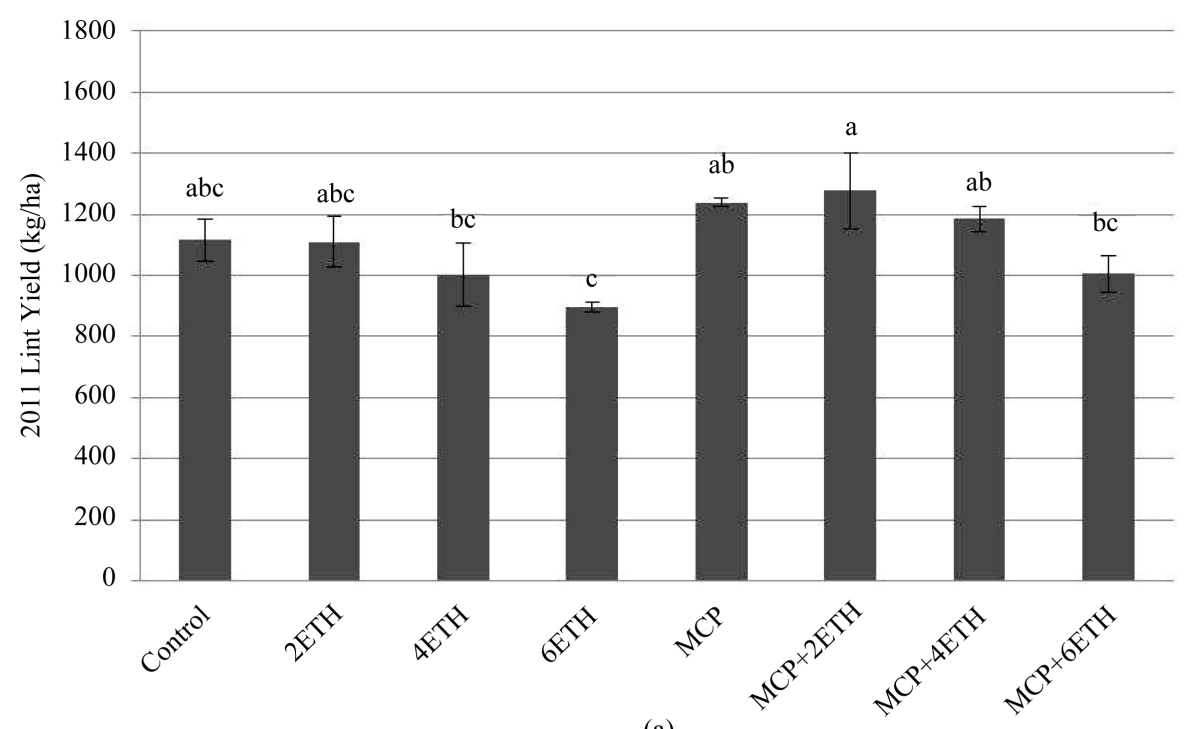

(a)

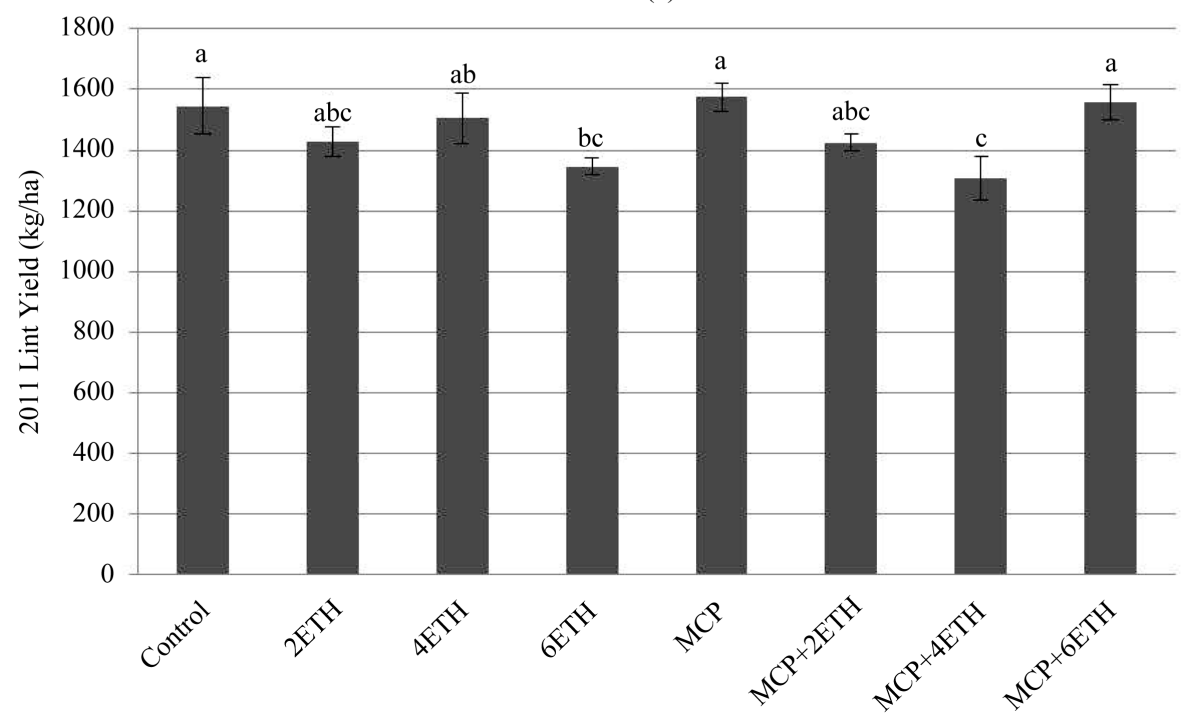

(b)

Figure 1. The effect of 1-MCP and ethephon on cotton lint yield in 2011 (a) and 2012 (b). Control $=$ the untreated control; $2 \mathrm{ETH}=146 \mathrm{~mL} \cdot \mathrm{ha}^{-1}$ Ethephon; $4 \mathrm{ETH}=292 \mathrm{~mL} \cdot \mathrm{ha}^{-1}$ Ethephon; $6 \mathrm{ETH}=438 \mathrm{~mL} \cdot \mathrm{ha}^{-1}$ Ethephon; MCP $=10 \mathrm{~g}$ a.i. $\mathrm{ha}^{-1} 1-\mathrm{MCP}$; MCP $+2 \mathrm{ETH}=10 \mathrm{~g}$ a.i. $\mathrm{ha}^{-1} \cdot 1-\mathrm{MCP}+146 \mathrm{~mL} \cdot \mathrm{ha}^{-1}$ Ethephon; MCP $+4 \mathrm{ETH}=10 \mathrm{~g}$ a.i. $\mathrm{ha}^{-1} 1-\mathrm{MCP}+292 \mathrm{~mL} \cdot \mathrm{ha}^{-1}$ Ethephon; MCP $+6 \mathrm{ETH}=10 \mathrm{~g}$ a.i. $\mathrm{ha}^{-1} 1-\mathrm{MCP}+428 \mathrm{~mL} \cdot \mathrm{ha}^{-1}$ Ethephon. Same letters above histograms represent non-significant differences $(\mathrm{P}=0.05)$. Vertical bars indicate SE.

\subsection{Yield Distribution}

To further analyze the yield distribution, boll set and weight were analyzed by fruiting position on sympodial branches and different node positions. According to orthogonal contrast, 1-MCP treatment increased boll weight on the second fruiting position for both years (Table 2). Additionally, in the year 2011, 1-MCP plus ethephon treatments impacted boll weight on main-stem nodes 11 to 15 compared to ethephon treatments alone. Thus, 1-MCP treatment increased boll weight in the second fruiting position and nodes 11 - 15 in cotton plants. Since the second position and nodes 11 - 15 contributes to an important part of the cotton yield, an improvement at these sites could make a significant difference in yield. Orthogonal contrast showed ethephon treatments decreased first position boll weight compared to the untreated control in 2012 (Table 2). This may partially explain the significant decrease in overall boll weight per plant and final lint yield caused by ethephon. 


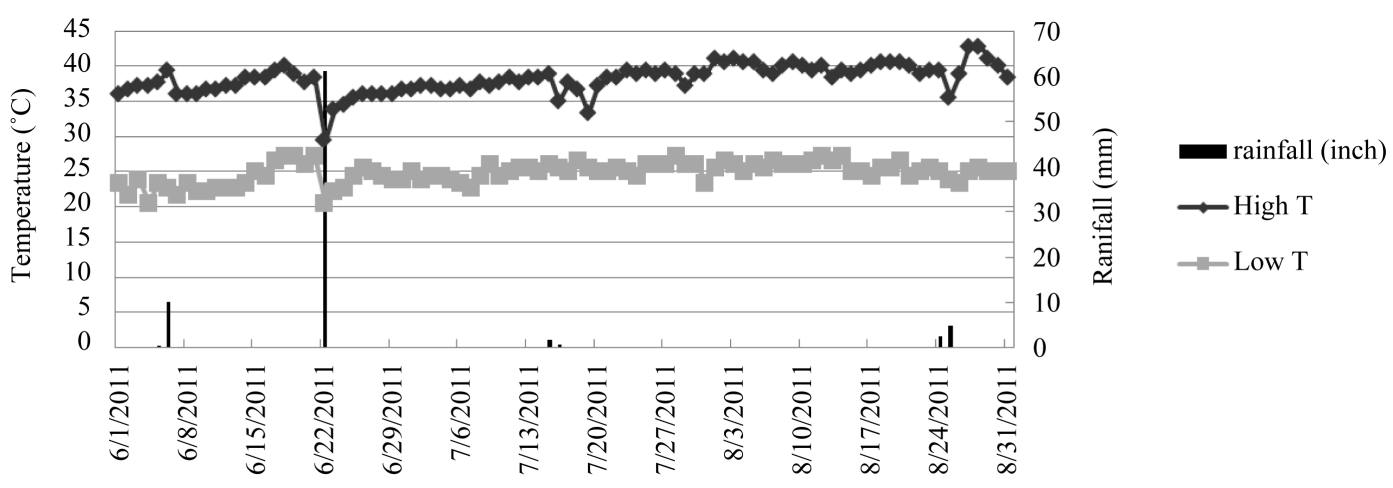

(a)

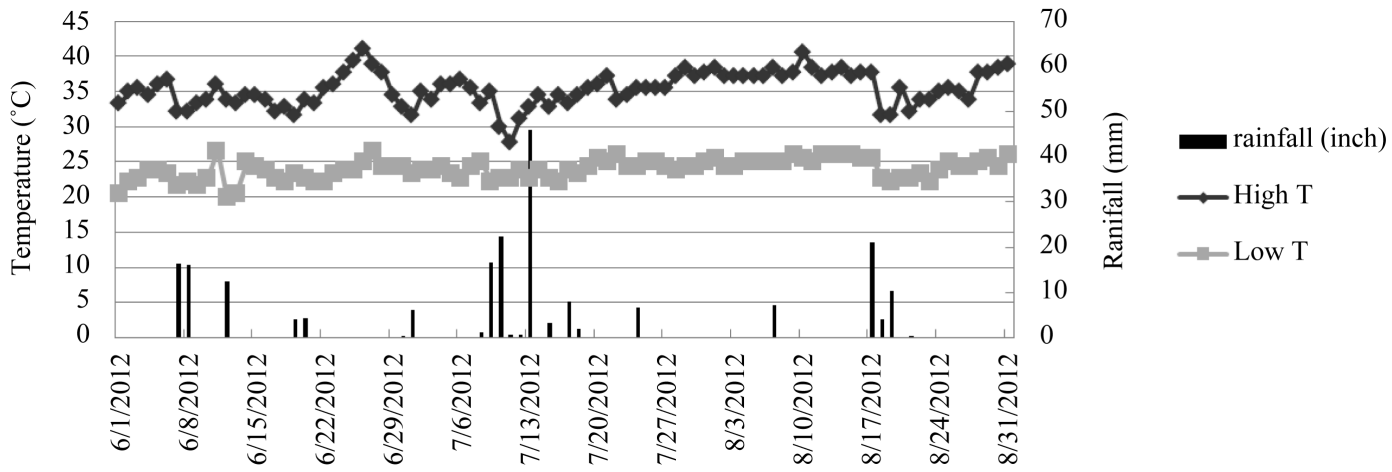

(b)

Figure 2. Weather data for 2011 (a) and 2012 (b).

Table 2. The effect of 1-MCP and ethephon on cotton boll weight on first position and second position of sympodial branches, node 6 - 10, node 11 - 15, node 16 - 20 of the main stem in 2011 and 2012. Same letters within each column represent non-significant differences $(\mathrm{P}=0.05)$.

\begin{tabular}{|c|c|c|c|c|c|c|c|c|c|c|c|c|}
\hline \multirow{3}{*}{ Treatment } & \multirow{2}{*}{ 1-MCP } & \multirow{2}{*}{ Ethephon } & \multicolumn{2}{|c|}{$\begin{array}{l}\text { First position boll } \\
\text { weight }\end{array}$} & \multicolumn{2}{|c|}{$\begin{array}{l}\text { Second position } \\
\text { boll weight }\end{array}$} & \multicolumn{2}{|c|}{$\begin{array}{l}\text { Node } 6 \text { - } 10 \\
\text { boll weight }\end{array}$} & \multicolumn{2}{|c|}{$\begin{array}{l}\text { Node } 11 \text { - } 15 \\
\text { boll weight }\end{array}$} & \multicolumn{2}{|c|}{$\begin{array}{c}\text { Node } 16 \text { - } 20 \\
\text { boll weight }\end{array}$} \\
\hline & & & 2011 & 2012 & 2011 & 2012 & 2011 & 2012 & 2011 & 2012 & 2011 & 2012 \\
\hline & g a.i. ha ${ }^{-1}$ & $\mathrm{~mL} \cdot \mathrm{ha}^{-1}$ & \multicolumn{10}{|c|}{ g.plant ${ }^{-1}$} \\
\hline 1 & 0 & 0 & $45.25 a$ & $42.44 a$ & 17.01ab & $9.52 b$ & $24.21 \mathrm{a}$ & $21.27 \mathrm{a}$ & 26.86ab & 24.58ab & 10.24ab & 11.18ab \\
\hline 2 & 0 & 146 & 41.33a & $35.90 \mathrm{ab}$ & 11.25ab & 10.54ab & $25.18 a$ & $19.77 \mathrm{a}$ & 20.40ab & 22.61ab & $8.71 \mathrm{~b}$ & $6.18 \mathrm{bc}$ \\
\hline 3 & 0 & 292 & $40.64 a$ & 34.41ab & 13.00ab & 11.01ab & $21.34 \mathrm{a}$ & $17.64 a$ & 20.54ab & $21.75 b$ & 13.14ab & 8.97abc \\
\hline 4 & 0 & 438 & $36.74 a$ & $30.84 \mathrm{~b}$ & $10.11 b$ & $10.17 \mathrm{~b}$ & $19.85 a$ & $14.51 \mathrm{a}$ & $18.89 \mathrm{~b}$ & 24.93ab & $8.80 \mathrm{ab}$ & $6.13 b c$ \\
\hline 5 & 10 & 0 & $44.03 a$ & 34.93ab & 17.47ab & 16.12ab & $26.22 \mathrm{a}$ & $22.94 a$ & 24.37ab & 27.30ab & 13.42ab & $5.79 b c$ \\
\hline 6 & 10 & 146 & $50.85 a$ & 40.51ab & $19.55 \mathrm{a}$ & 15.17ab & $23.70 \mathrm{a}$ & $20.82 \mathrm{a}$ & 30.63a & $30.81 a$ & $16.26 \mathrm{a}$ & 9.58abc \\
\hline 7 & 10 & 292 & $43.16 a$ & 35.03ab & 19.04a & 13.20ab & $24.03 a$ & 23.71a & 24.95ab & $21.20 \mathrm{~b}$ & 15.99ab & $4.13 c$ \\
\hline \multirow[t]{2}{*}{8} & 10 & 438 & $38.97 a$ & 34.78ab & 11.24ab & $17.82 \mathrm{a}$ & $20.65 a$ & $17.62 \mathrm{a}$ & 23.85ab & 28.70ab & $8.73 b$ & 13.08a \\
\hline & \multicolumn{2}{|c|}{ LSD (0.05) } & 18.41 & 9.72 & 8.49 & 7.43 & 8.29 & 9.72 & 10.85 & 8.56 & 7.50 & 6.12 \\
\hline \multicolumn{13}{|c|}{ Orthogonal contrast } \\
\hline \multicolumn{3}{|c|}{ Ethephon vs. ethephon + 1-MCP } & NS & NS & $*$ & * & NS & NS & $*$ & NS & NS & NS \\
\hline \multicolumn{3}{|c|}{ 1-MCP vs. 1-MCP absent } & NS & NS & NS & $* *$ & NS & NS & NS & NS & NS & NS \\
\hline \multicolumn{3}{|c|}{ Control vs. ethephon } & NS & * & NS & NS & NS & NS & NS & NS & NS & NS \\
\hline \multicolumn{3}{|c|}{ 1-MCP vs. 1-MCP + ethphon } & NS & NS & NS & NS & NS & NS & NS & NS & NS & NS \\
\hline \multicolumn{3}{|c|}{ Ethephon vs. ethephon absent } & NS & NS & NS & NS & NS & NS & NS & NS & NS & NS \\
\hline
\end{tabular}

*, **Significantly different at $\mathrm{P}=0.05$ and 0.01 , respectively. 


\subsection{Plant Growth Parameters}

Plant growth parameters were also recorded to test the effects of 1-MCP treatment. Orthogonal contrast revealed a significant 1-MCP effect on plant height and number of main-stem nodes for both years of the study. 1-MCP treated plants were taller with more main-stem nodes compared to the plants that did not receive 1-MCP treatment. However, treatments failed to show any ethephon effect on plant growth parameters for either year of the study (Table 3).

\subsection{Leaf Senescence}

Electrolyte leakage and chlorophyll fluorescence were measured to assess physiological parameters of the treated plants. These two traits are good indicators of leaf senescence. Fluorescence yield is measured to show the quantum efficiency of photosystem II [29]. The orthogonal contrast indicated that 1-MCP exhibited a beneficial effect on photosynthetic efficiency. The 1-MCP treated plants had a higher fluorescence yield than untreated ones in both years. In the year 2011, orthogonal contrast also showed an ethephon effect on fluorescence yield. Ethephon treatment decreased fluorescence compared to treatments receiving no ethephon (Table 4). Whereasethephon had a deleterious effect on photosystem II efficiency, 1-MCP treatment positively influenced the plants' ability to overcome the ethephon effect. In 2011, 1-MCP plus ethephon-treated plants had significantly higher fluorescence yield compared to their corresponding ethephon treated plants under the ethephon rate of 0,146 , and $292 \mathrm{~mL} / \mathrm{ha}$. However, when the ethephon rate was too high (as at $438 \mathrm{~mL} / \mathrm{ha}$ ), 1-MCP failed to show the protective effect on photosynthesis (Table 4).

Similar results were detected in membrane leakage data. Ethephon detrimentally affected membrane integrity and increased membrane damage (Table 4). Significant 1-MCP and ethephon effects were detected in both years of the present study. 1-MCP treated plants showed a lower membrane damage percent, which indicated better membrane integrity, compared to untreated plants according to orthogonal contrast. In the year 2012, ethephon plus 1-MCP treatments decreased membrane leakage compared to their corresponding ethephon treatments at all ethephon rates (Table 4). Thus, ethephon accelerated senescence while 1-MCP had the ability to delay senescence.

Table 3. The effect of 1-MCP and ethephon on plant height, and number of main stem nodes in 2011 and 2012. Same letters within each column represent non-significant differences $(\mathrm{P}=0.05)$.

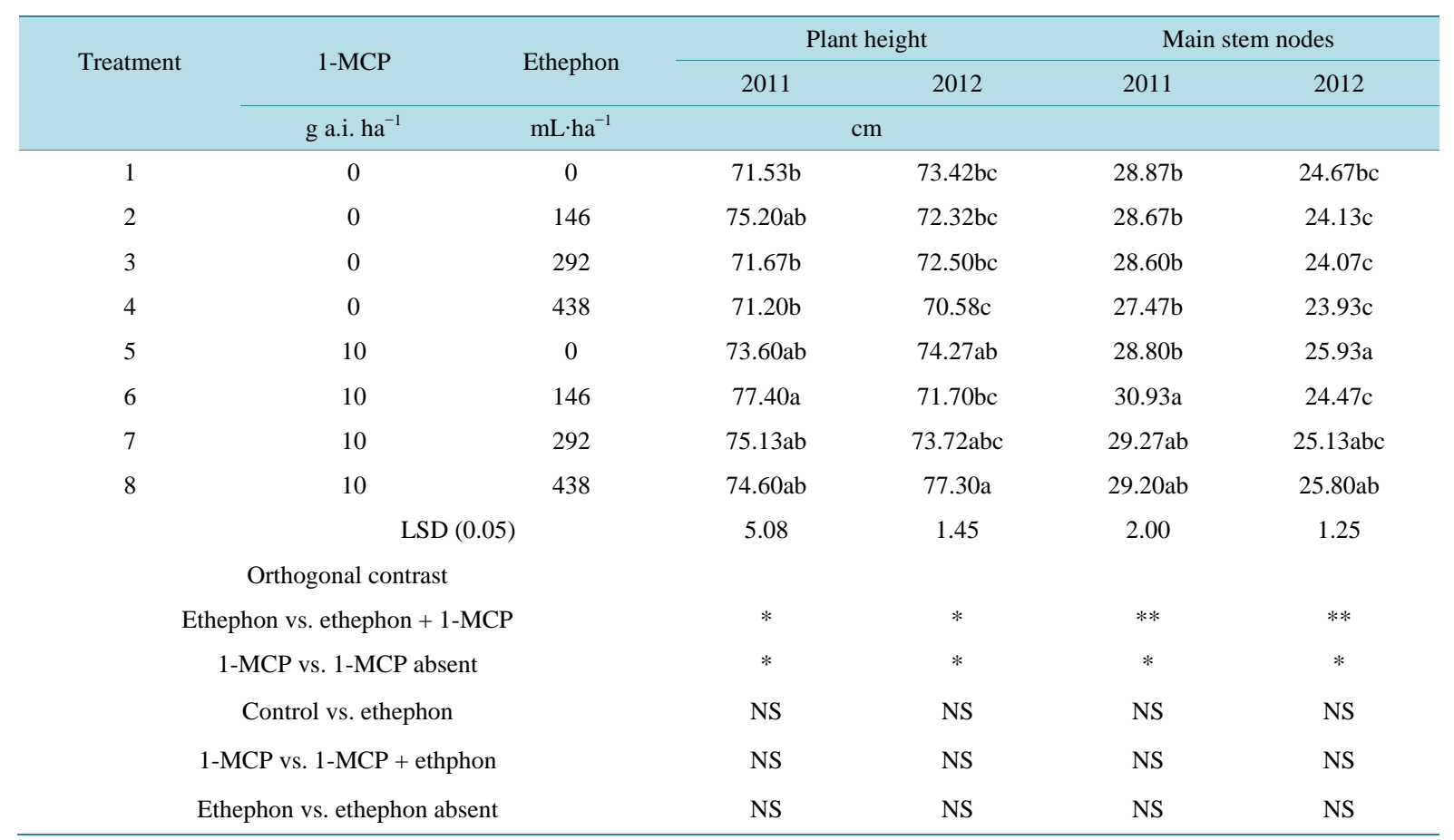

*, **Significantly different at $\mathrm{P}=0.05$ and 0.01 , respectively. 
Table 4. The effect of 1-MCP and ethephon on leaf chlorophyll fluorescence yield and membrane damage in 2011 and 2012. Same letters within each column represent non-significant differences $(\mathrm{P}=0.05)$.

\begin{tabular}{|c|c|c|c|c|c|c|}
\hline \multirow{2}{*}{ Treatment } & \multirow{2}{*}{ 1-MCP } & \multirow{2}{*}{ Ethephon } & \multicolumn{2}{|c|}{ Fluorescence yield } & \multicolumn{2}{|c|}{ Membrane damage } \\
\hline & & & 2011 & 2012 & 2011 & 2012 \\
\hline & g a.i. ha ${ }^{-1}$ & $\mathrm{~mL} \cdot \mathrm{ha}^{-1}$ & & & \multicolumn{2}{|c|}{$100 \%$} \\
\hline 1 & 0 & 0 & 0.539cd & 0.670ab & 9.95abc & $9.92 d$ \\
\hline 2 & 0 & 146 & $0.537 \mathrm{~cd}$ & $0.665 a b$ & 10.30abc & $11.95 \mathrm{ab}$ \\
\hline 3 & 0 & 292 & $0.532 \mathrm{~d}$ & 0.662ab & 11.53ab & 11.96ab \\
\hline 4 & 0 & 438 & $0.534 \mathrm{~cd}$ & $0.660 \mathrm{~b}$ & $11.96 \mathrm{a}$ & $12.06 \mathrm{a}$ \\
\hline 5 & 10 & 0 & $0.562 a$ & $0.677 \mathrm{a}$ & $8.79 \mathrm{c}$ & $10.88 \mathrm{c}$ \\
\hline 6 & 10 & 146 & $0.550 \mathrm{~b}$ & $0.676 a$ & $9.70 \mathrm{bc}$ & $10.43 \mathrm{~cd}$ \\
\hline 7 & 10 & 292 & $0.543 \mathrm{bc}$ & 0.666ab & $9.62 b c$ & $11.14 \mathrm{bc}$ \\
\hline \multirow[t]{2}{*}{8} & 10 & 438 & $0.536 \mathrm{~cd}$ & $0.675 a b$ & $10.97 a b$ & $11.02 \mathrm{c}$ \\
\hline & \multicolumn{2}{|c|}{ LSD (0.05) } & 0.011 & 0.016 & 2.06 & 0.92 \\
\hline \multicolumn{7}{|c|}{ Orthogonal contrast } \\
\hline \multicolumn{3}{|c|}{ Ethephon vs. ethephon + 1-MCP } & $* *$ & * & NS & $* *$ \\
\hline \multicolumn{3}{|c|}{ 1-MCP vs. 1-MCP absent } & $* *$ & $*$ & $*$ & $*$ \\
\hline \multicolumn{3}{|c|}{ Control vs. ethephon } & NS & NS & NS & $* *$ \\
\hline \multicolumn{3}{|c|}{ 1-MCP vs. 1-MCP + ethphon } & $* *$ & NS & NS & NS \\
\hline \multicolumn{3}{|c|}{ Ethephon vs. ethephon absent } & $* *$ & NS & $*$ & $* *$ \\
\hline
\end{tabular}

*, **Significantly different at $\mathrm{P}=0.05$ and 0.01 , respectively.

\section{Discussion}

The overall lint yield in 2012 was much higher than that of 2011 (Table 1). This phenomenon was likely the result of weather differences as bolls were set and developed under different environments for each year. It has also been reported that ethephon interaction with temperature impacts immature fruit shedding, cotton defoliation, and cotton boll opening [30]. Weather data showed that high temperature existed through the entire boll development period in 2011. In addition, cotton experienced a drought year in 2011. In 2012, temperature was lower during the boll development stage compared to 2011. These temperatures, however, were still considered to be high for cotton, but more precipitation was detected. Thus, cotton plants were under drought and greater heat stress in 2011 (Figure 2). In 2011, daily maximum and minimum temperature at application day was $37^{\circ} \mathrm{C}$ and $23^{\circ} \mathrm{C}$, respectively, and the average daily maximum and minimum temprerature in the following week was $38^{\circ} \mathrm{C}$ and $25^{\circ} \mathrm{C}$ with no precipitation. In the year 2012, the daily maximum and minimum temperature at the application day was $39^{\circ} \mathrm{C}$ and $24^{\circ} \mathrm{C}$, and the average daily maximum and minimum temprerature in the following week was $36^{\circ} \mathrm{C}$ and $24^{\circ} \mathrm{C}$. There was a precipitation of 0.25 and $6.35 \mathrm{~mm}$,respectively, at 5 and 6 days after application. Thus, the average weekly high temperature after application was $2^{\circ} \mathrm{C}$ higher in the year 2011 than in the year 2012. Because one week after application is a critical time for the chemical effect, the constant high temperature after application in the year 2011 also impacted the potential beneficial effect of 1-MCP. The ideal temperature is $28^{\circ} \mathrm{C} \pm 2^{\circ} \mathrm{C}$ for cotton growth [31]. High temperature during reproductive development adversely affects cotton growth and development and ultimately yields [32] [33]. The lower yield is caused by reduced boll size [32] [34], pollen infertility, and thus low seeds per boll [33], as well as a high fruit shedding rate [32] [34] [35]. In addition to these factors, with an increase intemperature, more biomass was allocated to roots, leaves, and stems because of reduced boll set [32]. Heat stress also impacts vegetative growth of cotton plants, with stressed plants typically exhibiting a reduced number of branches per plant with a lower branch length, shorter internodal length and fewer nodes [32]. High day temperatures may result in direct damage to components of leaf photosynthesis, thereby limiting photosynthetic potential and ultimately yield [32] [36].

The protective effect of 1-MCP on lint yield was more evident at the $292 \mathrm{~mL} \cdot \mathrm{ha}^{-1}$ ethephon treatment in 2011 (Figure 1(a)), whereas in 2012 the effect was more evident at the $438 \mathrm{~mL} \cdot \mathrm{ha}^{-1}$ ethephon (Figure 1(b)). This indicated that the higher degree of weather stress in 2011 combined with a lower ethephon rate equals the stress 
level of the lower degree of weather stress in 2012 combined with a higher ethephon rate. These data suggest that 1-MCP works more efficiently under some degree of stress. It also raises questions about the abiotic stress study: What is the internal stress level in the plants? How can we define the overall stress level? Is use of infrared thermometry (IRT) a good way to make this determination?

1-MCP treated plants were taller with more main-stem nodes compared to the plants that did not receive 1-MCP treatment (Table 3). These growth data also contribute to the explanation of the improved lint yield. Cotton lint yield is related to increases in plant height [37], and node number, since taller plants have a potential for producing more nodes which provide sites for development of reproductive branches to generate more bolls. Treatments failed to show any ethephon effect on plant growth parameters for either year of our study. In contrast, ethephon-treated plants were reported to exhibited height similar to or lower than the control, indicating a deleterious effect of ethephon on plant growth [28]. da Costa et al. (2011) [26] also found the detrimental effect of ethephon on plant growth: ethephon $\left(292 \mathrm{~mL} \cdot \mathrm{ha}^{-1}\right)$ reduced the number of reproductive nodes, which in combination with 1-MCP overcame this deleterious effect.

In our study, plants exposed to higher levels of ethylene exhibit premature senescence in the terms of increased membrane damage and lower photosynthetic quantum efficiency, while plants protected from ethylene effects show delayed senescence. When ethylene function was blocked, lower electrolyte leakage that is reflective of delayed senescence was detected in flower petals [14]-[16] and leaves [17] [20]. Reddy et al. (2004) [38] attributed the higher membrane damage to membrane lipid peroxidation in mulberry (Morusalba L.). Moreover, electrolyte leakage has been reported to be correlated with lipid peroxidation [39]. Our study confirmed that 1-MCP treatment lowered lipid peroxidation in stressed (heat stress and drought stress) cotton plants (unpublished data). Decreased malondialdehyde (MDA) level was also detected in 1-MCP treated soybean [27]. Another possible explanation for detected decreased membrane leakage is that ion transporters may also have been affected by 1-MCP treatment, impacting regulation of ion transport and thus impacting conductivity in the test solution. Further study is needed to test this hypothesis.

Ethephon or ethylene has been reported to decrease photosynthesis in soybean (Glycine max L. Merr.), mustard (Brassica juncea L.), and cotton [40]-[43]. A relation between decreased photosystem I and II activity to increased proteolysis and decreased chlorophyll content was found by using ethephon-treated isolated chloroplasts [44]. Thus, ethephon detrimentally affected photosynthesis, and ultimately carbon accumulation and the final yield in previous studies. Plants need oxygen for respiration and energy release. $\mathrm{CO}_{2}$ fixation is limited by environmental stresses, such as cold and high temperature, drought, and salt stress which reduce $\mathrm{NADP}^{+}$regeneration and thus induce accumulation of ROS including hydrogen peroxide $\left(\mathrm{H}_{2} \mathrm{O}_{2}\right)$, superoxide radical $\left(\mathrm{O}^{2-}\right)$, and hydroxyl radicals $\left(\mathrm{OH}^{-}\right)$in leaves [45] [46]. Previous cotton research showed that premature leaf senescence, reflected as aggregated membrane damage, lipid peroxidation, and decreased photosynthesis, is a result of imbalance of ROS metabolism. Under these conditions, more ROS are generated than removed [39]. 1-MCP increased the antioxidant potential in pear (Pyrusmalus L. cv. Blanquilla) by reducing ROS and increasing enzymatic antioxidant potential [47]. 1-MCP-treated plants exhibited less membrane damage and greater antioxidant enzyme activities of superoxide dismutase (SOD) and glutathione reductase (GR) in cotton and soybean [27] [48]. Thus the reduced leaf senescence traits in 1-MCP treated plants were probably due to less impact from ethylene activity and enhanced ROS scavenging ability of antioxidant enzymes.

There are some problems in using ethephon as the source of ethylene. Ethephon is converted to ethylene when $\mathrm{pH}$ values are larger than 8. Ethephon decomposition results in the release of chloride, ethylene, and phosphate, which means non-ethylene responses may exist. In weed seed germination studies only a small portion of ${ }^{14} \mathrm{C}-$ labeled ethephon was released as ethylene [45]. Others have also shown low and inconsistent ethephon conversion efficiency [46] [49]. Thus, the application of ethephon may not always mimic ethylene treatment.

\section{Conclusion}

1-MCP treatment showed the potential to increase cotton yield. First, 1-MCP treated plants were taller and had more nodes in both years of the study suggesting that plants can produce more branches to set more bolls, although it could also suggest that the more robust plants were caused by a lack of boll set. Second, 1-MCP treated plants exhibited higher photosynthetic efficiency and less membrane damage in both years reflecting delayed senescence and a longer photosynthetically active period to produce more assimilates for boll development. Third, 1-MCP treatment increased number of open fruit and open fruit weight per plant in 2012. These 
potentials for yield increase were realized in 2011 with 1-MCP treatment exhibiting higher lint yield. However, no significant yield increase was detected in 2012.

\section{Acknowledgements}

We are grateful for the financial support from AgroFresh. We also would like to thank Clayton Lewis and the entire Cotton Physiology Workgroup for their assistance for the field study. I also appreciate the technical assistant provided by Dr. Hongwen Su and Dr. Yujin Wen.

\section{References}

[1] Jackson, M.B. and Osborne, D.J. (1970) Ethylene, the Natural Regulator of Leaf Abscission. Nature, 225, $1019-1022$. http://dx.doi.org/10.1038/2251019a0

[2] Jordan, W.R., Morgan, P.W. and Davenpor, T.L. (1972) Water Stress Enhances Ethylene-Mediated Leaf Abscission in Cotton. Plant Physiology, 50, 756-758. http://dx.doi.org/10.1104/pp.50.6.756

[3] Suttle, J.C. and Hultstrand, J.F. (1991) Ethylene-Induced Leaf Abscission in Cotton Seedlings-The Physiological Bases for Age-Dependent Differences in Sensitivity. Plant Physiology, 95, 29-33. http://dx.doi.org/10.1104/pp.95.1.29

[4] Lipe, J.A. and Morgan, P.W. (1973) Ethylene, a Regulator of Young Fruit Abscission. Plant Physiology, 51, 949-953. http://dx.doi.org/10.1104/pp.51.5.949

[5] Guinn, G. (1976) Water Deficit and Ethylene Evolution by Young Cotton Bolls. Plant Physiology, 57, 403-405. http://dx.doi.org/10.1104/pp.57.3.403

[6] Guinn, G. (1982) Causes of Square and Boll Shedding in Cotton. In: USDA Technical Bulletins, US Government Printing Office, Washington DC, 1-22.

[7] Guinn, G. (1982) Fruit Age and Changes in Abscisic-Acid Content, Ethylene Production, and Abscission Rate of Cotton Fruits. Plant Physiology, 69, 349-352. http://dx.doi.org/10.1104/pp.69.2.349

[8] Lieberman, M. (1979) Biosynthesis and Action of Ethylene. Annual Review of Plant Physiology and Plant Molecular Biology, 30, 533-591. http://dx.doi.org/10.1146/annurev.pp.30.060179.002533

[9] Morgan, P.W. and Drew, M.C. (1997) Ethylene and Plant Responses to Stress. Physiologia Plantarum, 100, 620-630. http://dx.doi.org/10.1111/j.1399-3054.1997.tb03068.x

[10] McMichael, B.L. (1979) The Influence of Plant Water Stress on Flowering and Fruiting in Cotton. National Cotton Council, Memphis, Tennessee.

[11] Gan, S. and Amasino, R.M. (1997) Making Sense of Senescence (Molecular Genetic Regulation and Manipulation of Leaf Senescence). Plant Physiology, 113, 313-319.

[12] Pierik, R., Sasidharan, R. and Voesenek, L. (2007) Growth Control by Ethylene: Adjusting Phenotypes to the Environment. Journal of Plant Growth Regulation, 26, 188-200. http://dx.doi.org/10.1007/s00344-006-0124-4

[13] Young, T.E., Meeley, R.B. and Gallie, D.R. (2004) ACC Synthase Expression Regulates Leaf Performance and Drought Tolerance in Maize. Plant Journal, 40, 813-825. http://dx.doi.org/10.1111/j.1365-313X.2004.02255.X

[14] Faragher, J.D., Wachtel, E. and Mayak, S. (1987) Changes in the Physical State of Membrane Lipids during Senescence of Rose Petals. Plant Physiology, 83, 1037-1042. http://dx.doi.org/10.1104/pp.83.4.1037

[15] Sisler, E.C., Dupille, E. and Serek, M. (1996) Effect of 1-Methylcyclopropene and Methylenecyclopropane on Ethylene Binding and Ethylene Action on Cut Carnations. Plant Growth Regulation, 18, 79-86. http://dx.doi.org/10.1007/BF00028491

[16] Sisler, E.C. and Serek, M. (1997) Inhibitors of Ethylene Responses in Plants at the Receptor Level: Recent Developments. Physiologia Plantarum, 100, 577-582. http://dx.doi.org/10.1111/j.1399-3054.1997.tb03063.x

[17] Wills, R.B.H., Ku, V.V.V. and Warton, M.A. (2002) Use of 1-Methylcyclopropene to Extend the Postharvest Life of Lettuce. Journal of the Science of Food and Agriculture, 82, 1253-1255. http://dx.doi.org/10.1002/jsfa.1188

[18] Bleecker, A.B. and Patterson, S.E. (1997) Last Exit: Senescence, Abscission, and Meristem Arrest in Arabidopsis. Plant Cell, 9, 1169-1179. http://dx.doi.org/10.1105/tpc.9.7.1169

[19] Gepstein, S. and Thimann, K.V. (1981) The Role of Ethylene in the Senescence of Oat Leaves. Plant Physiology, 68, 349-354. http://dx.doi.org/10.1104/pp.68.2.349

[20] Jiang, W., Sheng, Q., Zhou, X.J., Zhang, M.J. and Liu, X.J. (2002) Regulation of Detached Coriander Leaf Senescence by 1-Methylcyclopropene and Ethylene. Postharvest Biology and Technology, 26, 339-345. http://dx.doi.org/10.1016/S0925-5214(02)00068-6

[21] Kao, C.H. and Yang, S.F. (1983) Role of Ethylene in the Senescence of Detached Rice Leaves. Plant Physiology, 73, 
881-885. http://dx.doi.org/10.1104/pp.73.4.881

[22] Wright, P.R. (1999) Premature Senescence of Cotton (Gossypium hirsutum L.) —Predominantly a Potassium Disorder Caused by an Imbalance of Source and Sink. Plant and Soil, 211, 231-239. http://dx.doi.org/10.1023/A:1004652728420

[23] Blankenship, S.M. and Dole, J.M. (2003) 1-Methylcyclopropene: A Review. Postharvest Biology and Technology, 28, 1-25. http://dx.doi.org/10.1016/S0925-5214(02)00246-6

[24] Lavee, S. and Martin, G.C. (1981) Ethylene Evolution Following Treatment with 1-Aminocyclopropane-1-carboxylic Acid and Ethephon in an in Vitro Olive Shoot System in Relation to Leaf Abscission. Plant Physiology, 67, 1204-1207. http://dx.doi.org/10.1104/pp.67.6.1204

[25] Smith, C.W., Cothren, J.T. and Varvil, J.J. (1986) Yield and Fiber Quality of Cotton Following Application of 2-Chloroethyl Phosphonic Acid. Agronomy Journal, 78, 814-818. http://dx.doi.org/10.2134/agronj1986.00021962007800050014x

[26] da Costa, V.A., Cothren, J.T. and Bynum, J.B. (2011) Abiotic Stress Effects on Plant Growth and Yield Components of 1-Mcp Treated Cotton Plants. Agronomy Journal, 103, 1591-1596. http://dx.doi.org/10.2134/agronj2010.0481

[27] Djanaguiraman, M., Prasad, P.V.V. and Al-Khatib, K. (2011) Ethylene Perception Inhibitor 1-MCP Decreases Oxidative Damage of Leaves through Enhanced Antioxidant Defense Mechanisms in Soybean Plants Grown under High Temperature Stress. Environmental and Experimental Botany, 71, 215-223. http://dx.doi.org/10.1016/j.envexpbot.2010.12.006

[28] Kennedy, C.W., Smith, W.C. and Jones, J.E. (1991) Chemical Efficacy of Early Square Removal and Subsequent Productivity of Superokra-Leaf Cotton. Crop Science, 31, 791-796. http://dx.doi.org/10.2135/cropsci1991.0011183X003100030050x

[29] Maxwell, K. and Johnson, G.N. (2000) Chlorophyll Fluorescence: A Practical Guide. Journal of Experimental Botany, 51, 659-668. http://dx.doi.org/10.1093/jexbot/51.345.659

[30] Reddy, V.R. (1995) Modeling Ethephon Temperature Interactions in Cotton. Computers and Electronics in Agriculture, 13, 27-35. http://dx.doi.org/10.1016/0168-1699(95)00012-S

[31] Conaty, W.C., Burke, J.J., Mahan, J.R., Neilsen, J.E. and Sutton, B.G. (2012) Determining the Optimum Plant Temperature of Cotton Physiology and Yield to Improve Plant-Based Irrigation Scheduling. Crop Science, 52, 1828-1836. http://dx.doi.org/10.2135/cropsci2011.11.0581

[32] Hodges, H.F., Reddy, K.R., McKinion, J.M. and Reddy, V.R. (1993) Temperature Effects on Cotton. Mississippi Agriculture \& Forestry Experiment Station, Prairie.

[33] Pettigrew, W.T. (2008) The Effect of Higher Temperatures on Cotton Lint Yield Production and Fiber Quality. Crop Science, 48, 278-285. http://dx.doi.org/10.2135/cropsci2007.05.0261

[34] Reddy, K.R., Davidonis, G.H., Johnson, A.S. and Vinyard, B.T. (1999) Temperature Regime and Carbon Dioxide Enrichment Alter Cotton Roll Development and Fiber Properties. Agronomy Journal, 91, 851-858. http://dx.doi.org/10.2134/agronj1999.915851x

[35] Zhao, D., Reddy, K.R., Kakani, V.G., Koti, S. and Gao, W. (2005) Physiological Causes of Cotton Fruit Abscission under Conditions of High Temperature and Enhanced Ultraviolet-B Radiation. Physiologia Plantarum, 124, 189-199. http://dx.doi.org/10.1111/j.1399-3054.2005.00491.x

[36] Wise, R.R., Olson, A.J., Schrader, S.M. and Sharkey, T.D. (2004) Electron Transport Is the Functional Limitation of Photosynthesis in Field-Grown Pima Cotton Plants at High Temperature. Plant, Cell and Environment, 27, 717-724. http://dx.doi.org/10.1111/j.1365-3040.2004.01171.x

[37] Boquet, D.J., Hutchinson, R.L. and Breitenbeck, G.A. (2004) Long-Term Tillage, Cover Crop, and Nitrogen Rate Effects on Cotton: Yield and Fiber Properties. Agronomy Journal, 96, 1436-1442. http://dx.doi.org/10.2134/agronj2004.1436

[38] Reddy, A.R., Chaitanya, K.V., Jutur, P.P. and Sumithra, K. (2004) Differential Antioxidative Responses to Water Stress among Five Mulberry (Morus alba L.) Cultivars. Environmental and Experimental Botany, 52, 33-42. http://dx.doi.org/10.1016/j.envexpbot.2004.01.002

[39] Liu, X.Z. and Huang, B.R. (2000) Heat Stress Injury in Relation to Membrane Lipid Peroxidation in Creeping Bentgrass. Crop Science, 40, 503-510. http://dx.doi.org/10.2135/cropsci2000.402503x

[40] Gunderson, C.A. and Taylor, G.E. (1991) Ethylene Directly Inhibits Foliar Gas-Exchange in Glycine max. Plant Physiology, 95, 337-339. http://dx.doi.org/10.1104/pp.95.1.337

[41] Kays, S.J. and Pallas, J.E. (1980) Inhibition of Photosynthesis by Ethylene. Nature, 285, 51-52. http://dx.doi.org/10.1038/285051a0

[42] Khan, N.A. (2004) An Evaluation of the Effects of Exogenous Ethephon, an Ethylene Releasing Compound, on Pho- 
tosynthesis of Mustard (Brassica juncea) Cultivars that Differ in Photosynthetic Capacity. BMC Plant Biology, 4, 21. http://dx.doi.org/10.1186/1471-2229-4-21

[43] Pettigrew, W.T., Heitholt, J.J. and Meredith, W.R. (1993) Early-Season Ethephon Application Effects on Cotton Photosynthesis. Agronomy Journal, 85, 821-825. http://dx.doi.org/10.2134/agronj1993.00021962008500040008x

[44] Choe, H.T. and Whang, M. (1986) Effects of Ethephon on Aging and Photosynthetic Activity in Isolated-Chloroplasts. Plant Physiology, 80, 305-309. http://dx.doi.org/10.1104/pp.80.2.305

[45] Goudey, J.S., Saini, H.S. and Spencer, M.S. (1987) Uptake and Fate of Ethephon (2-Chloroethyl Phosphonic Acid) in Dormant Weed Seeds. Plant Physiology, 85, 155-157. http://dx.doi.org/10.1104/pp.85.1.155

[46] Turnbull, C.G.N., Sinclair, E.R., Anderson, K.L., Nissen, R.J., Shorter, A.J. and Lanham, T.E. (1999) Routes of Ethephon Uptake in Pineapple (Ananas comosus) and Reasons for Failure of Flower Induction. Journal of Plant Growth Regulation, 18, 145-152. http://dx.doi.org/10.1007/PL00007062

[47] Larrigaudière, C., Vilaplana, R., Soria, Y. and Recasens, I. (2004) Oxidative Behaviour of Blanquilla Pears Treated with 1-Methylcyclopropene during Cold Storage. Journal of the Science of Food and Agriculture, 84, 1871-1877. http://dx.doi.org/10.1002/jsfa.1850

[48] Kawakami, E.M., Oosterhuis, D.M. and Snider, J.L. (2010) 1-Methylcyclopropene Effects on the Physiology and Yield of Field-Grown Cotton. Journal of Cotton Science, 14, 233-239.

[49] Zhang, W. and Wen, C.K. (2010) Preparation of Ethylene Gas and Comparison of Ethylene Responses Induced by Ethylene, ACC, and Ethephon. Plant Physiology and Biochemistry, 48, 45-53. http://dx.doi.org/10.1016/j.plaphy.2009.10.002 
Scientific Research Publishing (SCIRP) is one of the largest Open Access journal publishers. It is currently publishing more than 200 open access, online, peer-reviewed journals covering a wide range of academic disciplines. SCIRP serves the worldwide academic communities and contributes to the progress and application of science with its publication.

Other selected journals from SCIRP are listed as below. Submit your manuscript to us via either submit@scirp.org or Online Submission Portal.
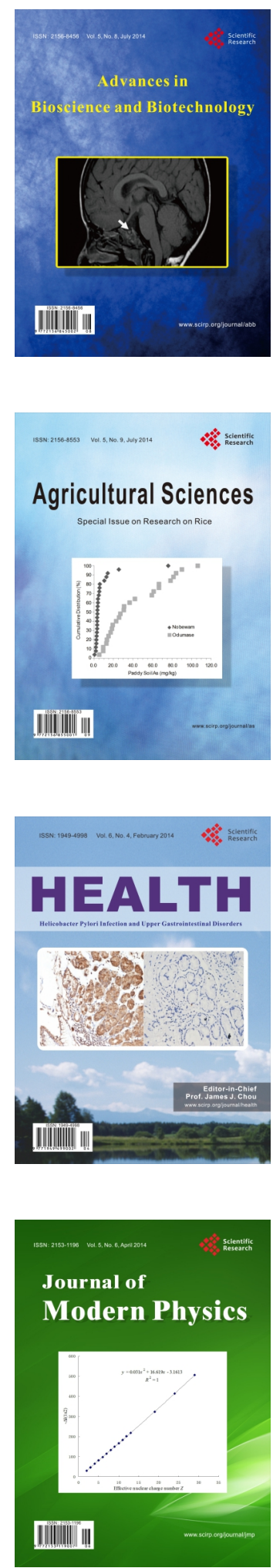
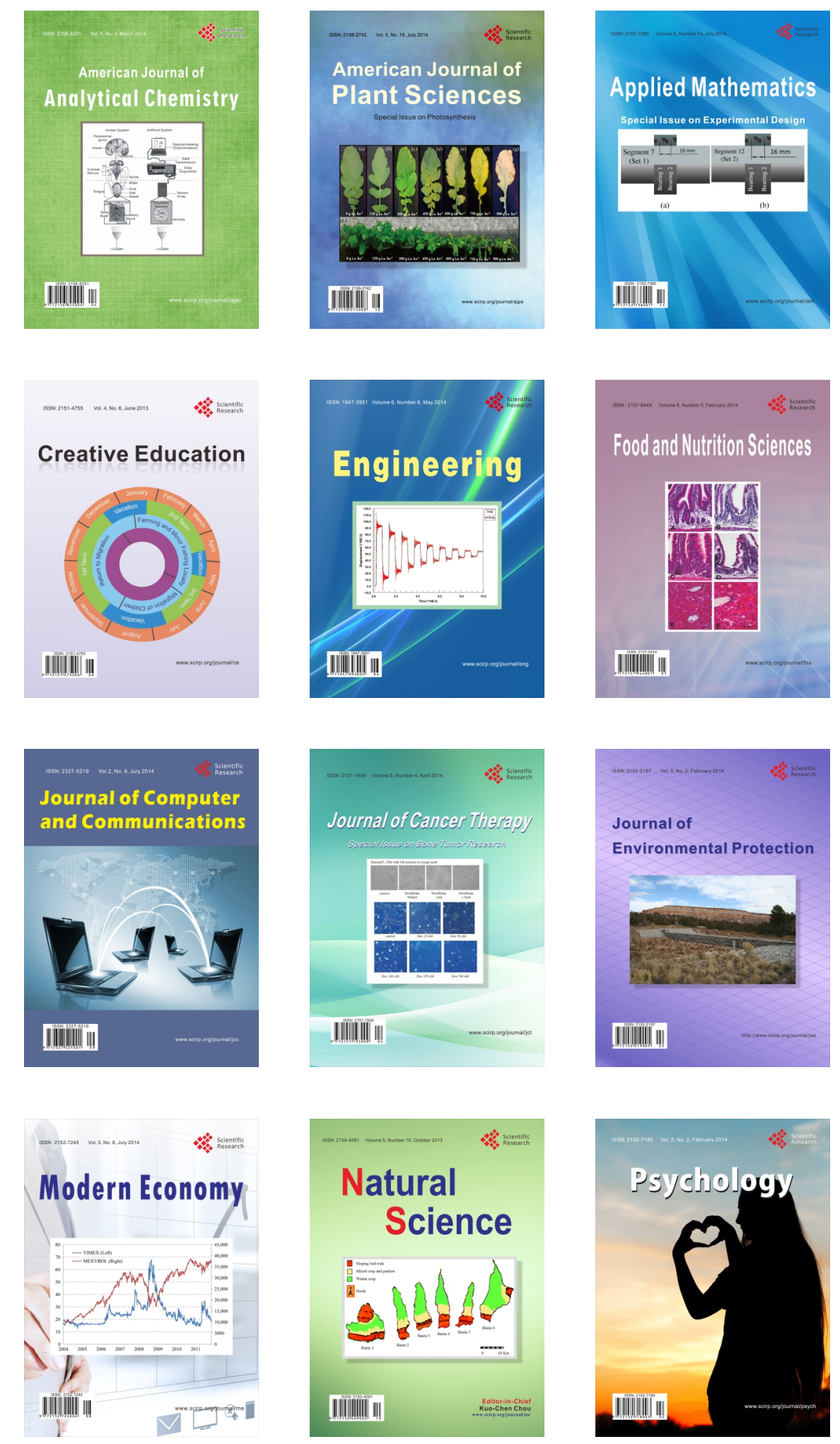